\title{
Correction to: Impacts of Suspended Sediment on Nearshore Benthic Light Availability Following Dam Removal in a Small Mountainous River: In Situ Observations and Statistical Modeling
}

\author{
H.E. Glover ${ }^{1}$ (I) $\cdot$ A. S. Ogston ${ }^{1}$ - I. M. Miller ${ }^{2}$ E. F. Eidam ${ }^{3}$ - S. P. Rubin ${ }^{4} \cdot$ H. D. Berry ${ }^{5}$
}

Published online: 28 August 2019

(C) Coastal and Estuarine Research Federation 2019

\section{Correction to: Estuaries and Coasts}

https://doi.org/10.1007/s12237-019-00602-5

In the original article the following disclaimer is missing:

Any use of trade, firm, or product names is for descriptive purposes only and does not imply endorsement by the U.S. Government.

H.E. Glover

hglover@uw.edu

\section{A. S. Ogston}

ogston@uw.edu

I. M. Miller

immiller@uw.edu

E. F. Eidam

efe@email.unc.edu

S. P. Rubin

srubin@usgs.gov

H. D. Berry

helen.berry@dnr.wa.gov
University of Washington, School of Oceanography, Box 357940, Seattle, WA 98195, USA

2 Washington Sea Grant, 3716 Brooklyn Avenue NE, Seattle, WA 98105, USA

3 University of North Carolina at Chapel Hill, 3202 Venable and Murray Halls, CB 3300, Chapel Hill, NC 27599, USA

4 Western Fisheries Research Center, U.S. Geological Survey, 6505 NE 65th St, Seattle, WA 98115, USA

5 Washington Department of Natural Resources, MS 47027, Olympia, WA 98504, USA 